\title{
The Dynamic of Religious Life: A Study of Conflict and Integration of Ahmadiyah in Garut, Tasikmalaya and Kuningan, West Java
}

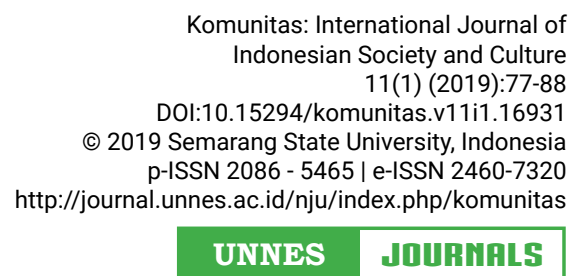

omunitas: International Journal of Society and Culture v11i1.16931 9 Semarang State University, Indonesia UNNES JDURNALS

\section{Ahmad Ali Nurdin', Adon Nasrullah Jamaludin², Encup Supriatna ${ }^{3}$, Kustana ${ }^{4}$}

1,2,3,4Sunan Gunung Djati State Islamic University , Bandung, West Java, Indonesia

Received: August 30, 2018; Accepted: March 1, 2018; Published: March 30, 2019

\begin{abstract}
The conflict does not automatically lead to disintegration. Sociologist like Georg Simmel and Lewis Coser reinforce this assumption. Conflict can also function to strengthen social groups and restore social integration. Conflict and integration (harmony) like two sides of a coin, different but still one. This paper supports the assumption above. After the conflict between the community and Ahmadiyah's followers in the three Regencies (Garut, Tasikmalaya and Kuningan), they live in harmony (integration). This fact in line with the argument of Georg Simmel and Lewis Coser. This study showed that the conflicts occurred in three regencies (Garut, Tasikmalaya and Kuningan), did not make the Ahmadiyah adherents disintegrated and crumbled. But on the contrary, Ahmadiyah followers increasingly integrated, solid and live co-exist with the non-Ahmadiyah community and live harmoniously.
\end{abstract}

\section{Keywords}

keyword

\section{INTRODUCTION}

The development of Ahmadiyah in West Java was begun in 1932 (Zulkarnain 2005, p. 235). Ahmadiyah was firstly known by people of West Java after the public debate on Ahmadiyah's teachings between Persatuan Islam or PERSIS Muslim organization led by A. Hasan and Ahmadiyah led by Rahmat Ali on 14-16 April 1933 (Alam 2005). There were at least three consecutive debates among them on several themes such as the death or life of Prophet Isa Al-Masih (28 September 1933), the present of the prophet after the last Prophet Muhammmad (29 September 1933) and the truth of Hazrat Mirza Ghulam Ahmad's preacher (30 September 1933).

Those debates above attracted people and got great concerned of Muslim community in West Java. Media covered those debates extensively, which made people more curious and want to know what Ahmadiyah was. Many people in several regions in West Java such as in Tasikmalaya, Singaparna and Garut joined the Ahmadiyah. Since then, Ahmadiyah's followers were getting bigger and bigger and extended to other places in West Java such as Jatibarang, Cianjur, Bandung, Bogor, Bekasi and Kuningan. Currently, Garut, Tasikmalaya and Kuningan are considered as basis places of Ahmadiyah's

\footnotetext{
Corresponding author

Jl. A.H. Nasution No.105, Cipadung, Cibiru, Bandung City, West Java 40614

Email

nurdinster@gmail.com
} 
development in West Java (Personal Interview with $\mathrm{H}$. Rafani Akhyar, head of Forum Kerukunan Umat Beragama (Religious Harmony Forum) of West Java, 5 June 2018). These places not only have had specialhistorical establishment of Ahmadiyah, but also have been considered as the top three Ahmadiyah's followers in West Java.

In its early development, Ahmadiyah's preaching (dakwah) did not face any challenges and Muslim people in general tended to accept their religious teachings. In addition, the Indonesian government officially admitted Ahmadiyah's community as a legal organization through a decree of Ministry of Law No. JA.5/23/13 on 13 March 1953 (Burhani 2014; Connley 2016). This decree was strengthened by another official declaration from Directorate for Relations with Political Institutions of Ministry Home affairs with decision No. 75//DI/VI/2003 on 5 June 2003 stated that Ahmadiyah is a legal organization. These two official decision letters from the government showed that Ahmadiyah has a solid legal status on the ground. Ahmadiyah's teachings also were not deviant because their teachings were based on Pancasila as mentioned in chapter two of its organizational constitution (Sidik 2008, p. 35).

Unfortunately, when its followers getting bigger and many Ahmadiyah's teachings are questioned by the people, there are many critics and rejections from the people. Muslim society not only protested but also discriminated Ahmadiyah's followers, and even expelled them from their own places (Purwanto 2008). In fact, the rejection to Ahmadiyah's followers has been started since 1950s. It escalated, however, when the Indonesian Council of Ulama (MUI) issued the fatwa in 1984, stating that Ahmadiyah was a deviant and non-Islamic group and followed by another 2005's fatwa that banned Ahmadiyah's activities. This 2005 MUI's fatwa, at the same time, also prohibited pluralism, liberalism and secularism (As'ad 2009, p. 402).

After this 2005 fatwa being issued, many Islamic groups reacted negatively to the Ahmadiyah. Some Islamic group used this fatwa to legitimize their action to use violence and attack Ahmadiyah's followers (Gillespie 2007). They attacked Ahmadiyah's institutions in West Java, East Lombok, and other places in Indonesia that led to the closure of several Ahmadiyah's mosques in the country (Hefner \& Fauzi 2014, p.35). The rejection to Ahmadiyah reached its peak when the government of Indonesia announced a Joint Three Ministerial Decree in 2008 banning the activities of Ahmadiyah (Fadhillah 2008) and warned them to return to 'the true Islam" if they claimed to be a Muslim. In West Java particularly, the Governor also announced the governor law No. 122011 that banned all Ahmadiyah's activities in West Java province.

The issue of MUI's fatwas and governor law have paved the way for several Islamic groups such as Front Pembela Islam FPI, Gerakan Anti Ahmadiyah (Geram), Forum Ulama Indonesia (FUI), Hizbut Tahrir Indonesia (HTI) to react negatively against Ahmadiyah. The attacks and violence against Ahmadiyah occurred in several places in West Java such as in Manis Lor, Tasikmalaya, Garut, and Majalengka. These actions could be seen as a proof that religious intolerance escalated in West Java. The violence reached its peak when the followers of Ahmadiyah in Cikeusik-Pandeglang was attacked by more than hundreds of Cikeusik residents on 6 February 2011. In this attack, three Ahmadiyah followers were killed. The attack also destroyed many properties belong to Ahmadiyah's followers such as cars, motorcycles and houses (Naipospos 2013, p.67).

In the last decade, many intolerance acts and religious violence have happened in Indonesia. Research done by Setara Institute showed the increasing trends of religious violence in the country. In their report (January-June 2016), Setara Institute noted that there were 62 religious intolerances issues in 8 provinces in Indonesia (Setara Institute 2016, p.2). The same as Setara Institute, The Wahid Institute reported 190 cases related to religious intolerance in Indonesia. It increased twenty percent from that of in 2014 (Wahid Institute 2015, p. 32).

From those two reports above, it is interesting to note that the province of West Java was among the highest rate in terms 
of religious intolerance acts in the country. Setara Institute reported 41 cases of religious intolerances in the region, followed by Jakarta province (7 cases) and East Java (6 cases). Almost at the same time, the Wahid Institute noted 46 cases of religious intolerance in West Java, followed by Aceh $(36$ cases), Jakarta (23 cases), Yogyakarta (10 cases), East Java (9 cases), Lampung (8 cases), Banten (7 cases) and Central Java (7 cases). Among those religious intolerance cases, the attack on Ahmadiyah's folllowers placed the top on the list which 12 to 14 cases in average (Wahid Institute 2015, p.33).

The questions remained is to whether these attacks have ended the case of Ahmadiyah's movement in the country or not. From the research findings in three regions in West Java (Garut, Tasikmalaya and Kuningan), we found that the conflict (discriminations, violence and attacks) did not automatically lead to disintegration or difunctional among the society. The Ahmadiyah's followers in these three research sites have been existing and living harmoniously with other non-Ahmadiyah's members in the society. The same as Ahmadiyah's followers, the non-Ahmadiyah people seem not to care about governmental rules that restricted and banned Ahmadiyah's activities. The people in general seem to let Ahmadiyah's activities and do not want to keep fighting with the Ahmadiyah's followers.

The phenomenon above is interesting to be discussed, particularly on the pattern of relation between two conflicting groups. On the one hand, it has a conflict potential and on the other hand, it could lead to an integration in the society. In addition, post the conflict, the integration seems to be more prevail in the conflicting area. To examine this phenomenon, we used conflict theory proposed and popularized by Georg Simmel (Gross 2003) and Lewis Coser (Coser 1956; Coser 1957), as well as dimension of social capital theory from Bain and Hicks (1998).

For Lewis A. Coser, conflict has not led automatically to negative impacts but also has a positive function. One of positive function of the conflict is paving the way to social integration in the society (Ritzer \& Goodman 2004, p.159; Coser 1957). Coser's argument was supported by Ralf Dahrendorf who argued that the society always showed their "two faces": a conflict and an integration. In other words, conflict and integration are like a coin which cannot be separated in the society (Dahrendorf 1986, p.87). Conflict and integration have a mutual relationship. On the one hand, there is not a conflict before integration and on the other hand, there is not integration without a conflict previously. A potential conflict in a society will lead to a real conflict when horizontal and vertical factors met. In other words, ascribed factors such as ethnicity and religion encountered with achievements' factors such as income, residency and political position, and the intensity of conflict could even escalate. Conversely, if horizontal factors did not meet vertical factors, the intensity of conflict could decline and even could pave the way to the integration in the society.

A social capital theory by Bain and Hicks as cited by Rusydi Syahra (2003, p.9) proposed two social capital dimensions as a conceptual framework to measure the existence of social capital in conflict resolution. From these two dimensions, one dimension that is a cognitive dimension, could be used to analyze Ahmadiyah's conflict in three regions in West Java (Garut, Tasikmalaya and Kuningan). This cognitive dimension related to values, attitude and belief that influence trust, solidarity and reciprocity, could encourage people to cooperate to achieve a communal goal in society. There are two social capitals that the researchers concerned about, namely bonding social capital and a bridging social capital (Bain \& Hick, 1998).

Based on those two theories above, the researcher tries to capture the dynamic of religious life of Ahmadiyah's followers after repressive approaches of government and non-governmental alike. The three areas (Garut, Tasikmalaya and Kuningan) have been chosen by the researcher due to three reasons. The first reasons, in these areas, the conflict has been happening for several times. Secondly, the post conflict in these areas have led to an integration and harmonious life between Ahmadiyah and non- 
Ahmadiyah people. The last reason, these three regions are considered historically as a bases of Ahmadiyah's community in West Java with a huge number of its followers.

\section{METHOD}

This research employed a descriptivequalitative method. According to Morrow and Smith (2000), understanding and explaining meaning of participants are the major aims of the qualitative research. In Creswell's words (1998) qualitative research is "an inquiry process of understanding based on distinct methodological traditions of inquiry that explore a social or human problem." Here, the researcher could analyze holistically what has been reported by informant in a very natural setting. A range of qualitative research methods was used to gather data including, in-depth interview, observation, and documentation. In-depth interviews were used to gather data from key informants who understand issues in regard with intolerance issues in their places. The key informants are as follows: Head of Local Officer of Ministry of Religious Affairs (Kemenag) of Garut, Tasikmalaya dan Kuningan, Head of Forum Kerukunan Umat Beragama (FKUB) or Religious Harmony Forum, Head of KUA in district levels, village leaders, customs leader, head of youth in the village who know the issues related to the research. Observation was also used to add the data from the daily activities in the research site. Those activities include the daily interaction (in formal meetings or in everyday activities) between community leaders and religious leaders both Ahmadiyah and non-Ahmadiyah's followers and other community actors. All the data gathered are edited, classified, compared and interpreted.

\section{RESULT AND DISCUSSION}

\section{Conflict and Integration: A Case of Ahmadiyah in Tasikmalaya}

Ahmadiyah reached Tasikmalaya brought by Entoy Muhammad Toyyib. He was assigned by M. Rahmat Ali in the late 1934 to promote Ahmadiyah to Priangan areas such as Bandung, Sumedang, Cianjur, Garut, Tasikmalaya and Ciamis. Entoy's struggle to promote Ahmadiyah was quite successful. It could be seen from the fact that there was a first Ahmadiyah's organization in Tasikmalaya on May 1, 1941 (Sofianto 2011, p.91). In addition, he extended his promotion of Ahmadiyah to several sub-district in Tasikmalaya such as Singaparna, Salawu, Sukaraja and Sukaratu. From these four areas, Ahmadiyah developed very well in sub-districts of Singaparna and Salawu. In Singaparna, the village of Cipakat became the central basis of Ahmadiyah, while in Salawu, it centralized at the village of Tenjowaringin. According to official informant from the Ministry of Religious Affairs of Tasikmalaya, the Ahmadiyah's movement in the region could not be diminished. Ahmadiyah has been becoming part of historical development of Islamic community in Tasikmalaya. This means that Ahmadiyah could not be separated or uprooted from the people of Tasikmalaya (Personal Interview with Usep Saepudin Muhtar, Religious Affair Officer in Tasikmalaya, 28 June 2018). Thus, their existence has been accepted by Tasikmalaya's people and we only found a very rare conflict among Ahmadiyah and non-Ahmadiyah followers in the region.

The basis of Ahmadiyah in sub-district Salawu located at the village of Tenjowaringin (Personal Interview with Saeful Aziz, head of KUA Salawu, 23 July 2018). Even the head of this village is an Ahmadiyah's follower. The Ahmadiyah's development in this village was not only caused by the success of their preachers in the village, but also because of hereditary factor. Many Ahmadiyah's offspring have been living in the village from time to time. Thus, it is important to note that the Ahmadiyah and non-Ahmadiyah's followers live harmoniously in the village.

According to the head of village, Tenjowaringin has been an important basis for Ahmadiyah movement in the region. The population of this village in 2018 is around 5,097 people with 1,480 head of family (Kepala Keluarga). Among them, Ahmadiyah's followers are majority with 3.675 people and 
non-Ahmadiyah are around 1.422 people. Every village in Tenjowaringin has its own Ahmadiyah's leader; for example (1) village of Citeguh led by Kustiawan Ahmad, has 330 Ahmadiyah's members; (2). Village of Bojong Sirna, led by Yusuf Ahmad, has 155 members; (3). Village of Wanasigra, led by Yahya, has 1,074 members; (4). Village of Sukasari, led by Wawan, has 823 members; (5). Village of Cigunungtilu, led by Sukarsana, has 308 members; and (7). Village of Nagrag, led by lip Saripudin, has 585 members. The Ahmadiyah's members in the village of Tenjowaringin has seven mosques and 20 musholla (small mosque) (Personal Interview with Kodir, head of village of Tenjowaringin, 24 July 2018).

Meanwhile the Ahmadiyah's basis at the sub-district Singaparna located at Village of Cipakat. However, their numbers and development are not as significant compare to Ahmadiyah's member in Village of Tenjowaringin, Salawu. There are only 246 Ahmadiyah's members in Village of Cipakat. Most of them are Ahmadiyah's descendants, and only a few came from outside the village, called ghair (the other). Almost all Ahmadiyah's followers in the village of $\mathrm{Ci}$ pakat has its "blood" or family relationship. According to Asep Muhammad Nurman, head of KUA Singaparna (Personal Interview, 24 July 2018), there are several reasons why the number of Ahmadiyah's members in his village did not increase significantly from time to time as follows: (1). The village is very closed to Cipasung Pesantren (Cipasung Islamic Boarding School); the pesantren is considered to be a place that protect the pure of Islamic theology of the ummah. (2). There is a well-known restriction phrase in this village delivered by the parents to their children that is not to play in Babakan (a place where Ahmadiyah's followers reside); they kept telling their children from generation to generation that Ahmadiyah is an infidel and not-Islam; (3). The member of Ahmadiyah in the village of Cipakat is very small in number and they do not have significant power to compete with other nonAhmadiyah's people economically, politically and religiously.
The violence cases in these villages are very small in number. This, however, does not mean that there was not a conflict between Ahmadiyah and non-Ahmadiyah in Cipakat and Tenjowaringin at all. The rarely significant conflict in these villages could be understood because the majority of residences in these places are Ahmadiyah's followers. This could prevent other non-Ahmadiyah residence who do not like Ahmadiyah's members to take any protest actions. According to local official government or the head of village of Cipakat, Ahmadiyah's followers in his village are considered as a part of Muslim community. Thus, they both (Ahmadiyah and non-Ahmadiyah members) live harmoniously. When a conflict occurred in this village, it was most probably caused or triggered by people come from outside the village (Personal Interview with Apipudin, head of village of Cipakat, 24 July 2018).

There was an Ahmadiyah's conflict in the village of Cipakat from 2008 to 2012 . The conflict occurred after the governor of West Java issued the law that banned Ahmadiyah's movement in West Java province. According to the head of village Cipakat, Appipudin, the conflict actually was triggered by the people from outside Cipakat who made a provocation. Both Ahmadiyah and nonAhmadiyah's followers in this village live together harmoniously. The non-Ahmadiyah followers in my village do not care to whether people will follow Ahmadiyah's teaching or not as long as they do not bother each other. Thus, a social relationship among the members of community of Cipakat village is generally harmonious and peaceful. They respected each other and avoided the conflict. Meanwhile, the conflict in the village of Tenjowaringin has occurred from 2007 to 2012. Different from that of in Village of $\mathrm{Ci}^{-}$ pakat, the conflicts between Ahmadiyah and non-Ahmadiyah's followers in the village of Tenjowaringin have happened several times such as the attack, the fighting and other violence acts between Ahmadiyah and nonAhmadiyah's followers. Several Ahmadiyah's properties such as mosque, houses and even motorcycle have been attacked by nonAhmadiyah's people. 
After these conflicts above, however, the Ahmadiyah's followers did not automatically left the villages. They have been surviving and keep living in these places. As mentioned before, the main factor of the conflict was a provocation from the people outside the village who hate Ahmadiyah and provoked the people of Cipakat and Tenjowaringin to attack Ahmadiyah's followers. Thus, when the outsiders gave up and did not provoke them anymore, the Ahmadiyah's followers live peacefully and harmoniously with the non-Ahmadiyah people in these villages. This means that the non-Ahmadiyah members let Ahmadiyah's members to practice their belief in their daily life. In addition, the official local government in the villages also let the Ahmadiyah's followers to live side by side with the people as long as they do not bother each other.

The Ahmadiyah's community in village of Cipakat, on the one hand, kept continuing their daily activities as usual after the conflict of 2011 up to present. The non-Ahmadiyah, on the other hand, seem to "do not care" or Masa Bodoh with the Ahmadiyah's belief and religious practices as long as they do not bother Muslim community in the village. This attitude has been shown by Muslim community in village of Cipakat after the conflict. The people of Cipakat in general saw that Ahmadiyah's followers in their village are good people and they like Ahmadiyah's style in their preaching or dakwah. The peaceful dakwah strategy done by Ahmadiyah could be the reason why nonAhmadiyah's followers or Muslim community in general in this village, like them.

The Ahmadiyah's members in the village of Tenjowaringin followed the same path to survive. After the conflict, they live more harmonious with the Muslim community in the village. In addition, they respect each other. The Ahmadiyah's members in the village gave more respect to non-Ahmadiyah's followers. Instead of fighting-back or attacking-back whom attacked them before, the Ahmadiyah's community even helped non-Ahmadiyah community, particularly helped those who are economically weak and poor. In turn, much non-Ahmadiyah community gave sympathy to Ahmadiyah's members and some of them even follow and become the Ahmadiyah's members voluntarily.

Another strategy of Ahmadiyah's member in Tenjowaringin to survive after the conflict was using political approach. They tried to take over political positions in the village such as becoming a head of village. By holding a position as a head of village, it is easier for Ahmadiyah's community to spread their movement and enlarge their members. Thus, it is understandable that the Ahmadiyah's movement in the village of Tenjowaringin is quite strong compare to that of in Cipakat. Economically, the members of Ahmadiyah in Tenjowaringin are very strong. They dominated several economic sectors in the village such as trade, services and agricultural sectors. In a political arena, the Ahmadiyah's member has been very dominant as well. In the last nine consecutive periods of head of village of Tenjowaringin, only one head of village was nonAhmadiyah's member.

From the above discussion, it is clear that from the year of 2007 to 2012 , between Ahmadiyah and non-Ahmadiyah in those villages, sometimes they live harmoniously and on the other occasion the conflict occurred, they on and off. This phenomenon is strengthening Ralf Dahrendorf's theory stated that conflict and integration have a reciprocal relationship, meaning that there is not conflict if there is not integration previously, and conversely there is no integration if there is no conflict before. In fact, in these two villages, the current situation or in a post conflict period, they showed a very harmonious life (integration). This phenomenon is also strengthening Georg Simmel and Lewis Coser's argument stated that conflict should not automatically lead to destruction (disintegration); conversely, conflict sometimes is needed to keep a social relationship in the society (Saifuddin 1986, p.44). This situation is corresponded with the statement of head of Village of Cipakat, Apipudin who says:

A conflict did not solve the problem. Conflict could lead to furious life. Different 
belief among society is natural. Unity and life peacefully are more important for $\mathrm{Ci}$ pakat people. Thus, currently non-Ahmadiyah people did not care to whether their neighbor has different religious belief or not as long as they do not disturb each other (Personal Interview with Apipudin, 24 July 2018).

The view of Cipakat's people above corresponded with the idea of bonding social capital proposed by Bain and Hick. They argue that conflict could become a social capital to strengthen a social relationship among the community. The conflicted society put an integration as their priority to strengthen their harmonious relationship or make them more integrated in society.

\section{Conflict and Integration: The Case of Ahmadiyah in Garut}

Garut people firstly knew Ahmadiyah in 1936, brought by Abdul Wahid, an Ahmadiyah's preacher who came from Padang, West Sumatera. This could be seen from the fact that since 1936, there have been an Ahmadiyah's mosque in Sanding-Garut. Moreover, in 1938, there was an Ahmadiyah's branch located in Samarang-Garut. Basyari Hasan was the first Samarang people who became an Ahmadiyah's member (he then became the head of Ahmadiyah in Samarang branch). In 1939, Sukri Barmawi (a teacher at Hollandsch-Inlandsche School, HIS) then followed Basyari Hasan to become an Ahmadiyah's member and followed by his older brother Hasan Ahya Barmawi became a member in 1940.

Since its establishment, the Ahmadiyah's movement in Garut showed up and down development. According to $\mathrm{H}$. Endang Sutiana (an official person at the office of Ministry of Religious Affairs, Garut), the development of Ahmadiyah community in Garut could be seen from three factors namely biological, sociological and historical. Biologically and historically, the majority of current Ahmadiyah's community in Garut was being Ahmadiyah because of their parents and grandparents were Ahmadiyah's followers (Personal Interview, 26 June 2018). Up to present, there are 2000 members of
Ahmadiyah in Garut District. They live in several sub-districts such as Malangbong, Bayongbong, Cigedug, Cibatu, Wanaraja, Garut, Sukawening, Samarang, dan Cilawu (Personal Interview with Mukhsin, an official governmental officer in subdistrict $\mathrm{Ci}^{-}$ lawu, 20 July 2018).

Cilawu is considered as a main basis of Ahmadiyah in Garut. There are around 700 Ahmadiyah's followers in Cilawu who lives in several villages namely village of Sukamaju and village of Ngamplang. Sukamaju even was appointed as an Ahmadiyah official branch number 107. Based on the official letter from the Central Ahmadiyah's office in Jakarta No. 096/SK/2013 on 20 June 2013, the Sukamaju Ahmadiyah's branch for the period 2013-2016 was headed by Rohana. Thus, all Ahmadiyah's activities in Garut should be taken place in village of Sukamaju.

Before the governor of West Java issued a regulation to prohibit Ahmadiyah's activities in 2011, the activities of Ahmadiyah in Garut was very conducive. The Garut people, particularly those who live in Cilawu did not disturb the Ahmadiyah's activities. The Ahmadiyah and non-Ahmadiyah people live peacefully and harmoniously in the region. Ahmadiyah's followers were very well known as good community who love to help other Muslim communities. To help other peopler was the Ahmadiyah's strategy in their preaching in Cilawu. Through a very peaceful approach, the Ahmadiyah's followers were accepted by Muslim communities. They live side by side. The nonAhmadiyah's people then felt very sympathetic to Ahmadiyah's community which paved the way for them to join Ahmadiyah's community and became a member of Ahmadiyah. Many poor people in Cilawu-Garut appreciated the helps of Ahmadiyah to their community.

Due to their peaceful strategy, the Ahmadiyah in Garut developed significantly. However, their spirit to spread Ahmadiyah's teaching has been stopped by regulation issued by West Java Governor in 2011 to prohibit all Ahmadiyah's activities in West Java province. This regulation, for the people who hate Ahmadiyah, has been used as a 
tool to attack Ahmadiyah's movement. As a consequence, the Ahmadiyah's community in Garut received many pressures and discrimination from non-Ahmadiyah's community. Many Ahmadiyah's properties and their ritual places have been attacked by nonAhmadiyah's people. The people of Garut, particularly those who are anti-Ahmadiyah's movement such as Gerakan Anti Ahmadiyah (Geram) orAnti-AHmadiyah's Movement, Front Pembela Islam (FPI) or Islamic Defender Front and Hizbut Tahrir Indonesia (HTI), have made the situation getting worse and conflict escalated. From 2011 to 2013, the pressure on Ahmadiyah's raised up. They received many attacks and terrors from the non-Ahmadiyah community. In 2013, for example, there was a significant dispute between Ahmadiyah and non-Ahmadiyah's community on mosque's ownership in $\mathrm{Ny}$ alindung, Cilawu. However, the dispute can be solved through deliberation (musyawarah) among the people of Cilawu including polices, religious leaders, representative of Ahmadiyah's community and non-Ahmadiyah people (Personal Interview with Mukhsin, an official governmental officer in subdistrict Cilawu, 20 July 2018).

After 2015, the conflict between Ahmadiyah and non-Ahmadiyah seems to decrease significantly. On the one hand, the Ahmadiyah's group have been pressured by the governor's regulation to stop their activities; and on the other hand, many Ahmadiyah's members in Garut were aware of their mistake and tried to return to follow 'pure Islamic teachings' and separated from Ahmadiyah's community. However, there are many Ahmadiyah's member who still kept their membership and have been loyal to their community.

Thus, it is interesting to examine religious life of Ahmadiyah's members who hold strongly their belief and live in the middle of people or communities that dislike them. When the pressure from the community decrease, the Ahmadiyah's community in Cilawu are still existed in the region and they kept their daily activities. They build their more harmonious interaction with non-Ahmadiyah people and kept good relationships with the local government officials, polices and other religious leaders in the region.

From the above discussion, it is clear that the same as the Ahmadiyah in Tasikmalaya, the conflict of Ahmadiyah in Garut was caused by the non-Ahmadiyah's view about Ahmadiyah's teaching as a falsehood teaching that contradict a true Islamic teaching. However, at the end, the majority of people of Garut let the Ahmadiyah to hold their belief and run their activities. The local government official and religious leaders believe that if they kept the conflict, it will never solve the problem. The victims could be more and more, particularly they will lose many properties they built. Based on these considerations, religious leaders and local government officials tried their best to stop the conflict and intimidation. They let Ahmadiyah's community to live peacefully in Cilawu, Garut. It is for sure a dilemmatic for religious leaders and government officials in the region. On the one hand, they do not want to keep conflict continued and on the other hand they should follow the law issued by the West Java governor to ban Ahmadiyah's activities. However, the religious leaders, village leaders and local government officials of Cilawu choose not to follow governor's regulation and let the Ahmadiyah and non-Ahmadiyah to stop their conflict which was hard to solve (Personal Interview with Enceng Ishak, head of KUA Cilawu, 20 July 2018).

One of ideas proposed by leaders of village of Cilawu to solve the problem of Ahmadiyah was through guidance and counseling approaches. On the one hand, they let Ahmadiyah's community to do their activities as usual because they are part of Cilawu's community who have their own rights to live peacefully. On the other hand, in relating to their belief, religious leaders and community leaders of Cilawu gave them guidance and counseling on religious matters. The community leaders also monitored all Ahmadiyah's activities in the village in order not to ignite conflict with other nonAhmadiyah's members. Every Ahmadiyah's activities including their religious activities 
should be informed to local leaders. The local leaders also participated in arranging activities schedule of the Ahmadiyah's community in their region.

Through the above monitoring approaches, it is hoped that Ahamadiyah's community will live in this Cilawu village without any intimidation from non-Ahmadiyah people. In addition, religious leaders also kept informed "true" religious Islamic teaching to the Ahmadiyah's members because many Ahmadiyah's members in $\mathrm{Ci}^{-}$ lawu actually do not understand about Ahmadiyah's organization. Many of them are not aware about what Ahmadiyah's is. Many Cilawu's people joined Ahmadiyah because of social and economic reason, not religious reason. This idea was not only applied in Cilawu but also in other many subdistricts and villages in Garut.

For the reason above, the chief of KUA (Kantor Urusan Agama, Office of Religious Affairs) of Cilawu collaborated with religious leaders both from Ahmadiyah and non-Ahmadiyah community, scheduled all religious activities in the region. All religious activities such as religious sermons, religious speeches in Friday Prayer, religious teachings in mosques for children etc. were scheduled by office of religious affairs of $\mathrm{Ci}^{-}$ lawu. Although, the Ahmadiyah's community do not agree with this idea in the first place, but at the end they follow the idea because this is the only solution made by the official community leaders to solve the conflict. In fact, this win-win solution could be seen as a good compromise between Ahmadiyah and non-Ahmadiyah community in Garut which seems to be prevail for the time being. They are currently living harmoniously side by side without any prejudice between Ahmadiyah and non-Ahmadiyah community in the region.

The fact of Ahmadiyah's case in Garut above shows that the integration (harmony) is the final choice to solve the conflict. The integration could be the best way to end the conflict from the both sides (Ahmadiyah and non-Ahmadiyah groups). One form of integration used by religious and community leaders in Garut was to accommodate
Ahmadiyah's community to be integrated to the community and made them not to be an exclusive group. The exclusiveness actually that led to segregation and prejudice and paved the way to conflicts. The pattern to solve the conflict applied by religious and community leaders in Garut is in line with the argument of George Simmel and Lewis Coser who argue that conflict could create a new interaction pattern between two conflicting groups which is previously absent.

One of the new approaches as mentioned above is to accommodate and take hold the Ahmadiyah's followers to be taught true Islamic teachings. Before the conflict, this new approach was absent. Instead, the local government and the people of Garut only knew that Ahmadiyah is deviant group and should be banned and ousted from their place. But, in fact, banning them did not solve the problem and conflict kept happening. Through a new approach that is integrated them to the society seems to be a good solution. This integration solution is with the argument of Lewis Coser who said that conflict could pave the way to integrate those who are in a conflict situation.

\section{Conflict and Integration: The Case of Ahmadiyah in Kuningan}

Kuningan has been very well known by West Java people as a center of Ahmadiyah's movement, particularly in the village of Manis Lor. In a personal interview (6 August 2018), the head of KUA-Jalaksana, Mumuh Muhammad Ali, said that Ahmadiyah in Manis Lor has been living in this place since early Ahmadiyah's arrival in Kuningan back to 1954. Up to present, there are 3020 Ahmadiyah's folllowers among 4471 Manis Lor population (Personal Interview with Zanu, secretary of village, 7 August 2018). To strengthened their existence, Ahmadiyah's followers have built several mosques, musholla and religious educational institutions in the region. Even since the 1970s, the head of this villages and their staffs are from Ahmadiyah's followers. Thus, the existence of Ahmadiyah in this village was called minority-majority meaning that they are a minority group among Indonesian Muslim, 
but a majority group in this village.

Since its arrival in 1954 up to 1984, religious life of Ahmadiyah's followers in Kuningan have been up and down (Rosidin 2010). For thirty years, Ahmadiyah's leaders in Kuningan have promoted their teachings to Manis Lor people. It is reasonable then if they became a majority group in the region. This does not mean that there was not any single conflict between Ahmadiyah and non-Ahmadiyah in Manis Lor between 1954 and 1984. There are some conflicts, but only small and insignificant conflict between Ahmadiyah and non-Ahmadiyah in Manis Lor. However, after 1984 the conflict between them started to escalate particularly post 1998 Indonesian reformation era. When the euphoria of freedom after Soeharto stepped down in 1998 started and any religious or political organization are free to establish, it influenced religious life of minority group in Indonesia including Ahmadiyah's movement. When many religious groups established and showed their religious identity, the attack to Ahmadiyah which was considered as a deviant Islamic group escalated. This also influenced the relationship between Ahmadiyah and non-Ahmadiyah followers in Indonesia particularly in Kuningan. The conflict escalated and cannot be avoided.

The tension of the conflict increased after the governor of West Java and the regent of Kuningan district issued regulations to ban Ahmadiyah's activities in 2ooos. Ahmadiyah's followers in Manis Lor received several terrors, attacks and discredited with nasty commentaries from non-Ahmadiyah people. The struggle to solve the conflict through dialogues has been done by local governmental officials. However, they failed to solve the conflict and the protest to the existence of Ahmadiah in the region continued. There are at least three types of protest and attacks on Ahmadiyah's followers in Manis Lor. Firstly, the protest and attacks have been arranged by local people (non-Ahmadiyah followers in Manis Lor). Secondly, the protests have been arranged and coordinated by several mass organizations around Kuningan district such as Gamas (Gerakan Anti Maksiat or Ant-Bad Act
Movement), Barat (Barisan Anak Kuningan or Kuningan Boy Guard) and Gibas (Gerakan Inisiatif Anak Siliwangi or Initiative Movement of Siliwangi's Boy). They not only attacked Ahmadiyah's properties but also attacked Ahmadiyah's followers in Manis Lor. And thirdly, the attacks and protests have been coordinated by people and organizations who came from outside Kuningan such as from Indramayu and Cirebon. They protested and demanded the Kuningan local government to expel Ahmadiyah's followers from Manis Lor. In addition, the dynamic of conflict between 2000 and 2012 was very massive and escalated. Many nonAhmadiyah people attacked, destroyed, and burn Ahmadiyah's properties and facilities. This reached its peak in September 2012 when Ahmadiyah's followers could not have their rights to have electronic identity cards (KTP) from the local government.

After 2012's conflict, there was not any significant conflict and attacks anymore. The conflict seems to be diminished. Although there were several significant conflicts in Manis Lor previously, it did not lead to deactivation of Ahmadiyah's movement in the region. Conversely, it makes them integrated and stronger and paved the way for non-Ahmadiyah's group to neglect Ahmadiyah's movement anymore. Anti Ahmadiyah's groups in Manis Lor seem to be tolerate and do not care of Ahmadiyah's activities. The religious official (KUA) of the Jalaksana sub-district Mumuh Muhamad Ali, in a personal interview said that it is very difficult to dissolve Ahmadiyah's movement. Currently, the Ahmadiyah's group is very exclusive in Manis Lor and they do not accept the dakwah (Islamic preaching) if it is delivered by religious leader who came from outside the group. This means that Ahmadiyah's religious activities have only been done and held among their followers. To save their activities, Ahmadiyah's followers have their own religious places and facilities such as mosques and even special schools for their children. They have done so to keep their religious teaching authentic. The exclusiveness of Ahmadiyah's religious life in Kuningan has influenced 
their daily social interactions with nonAhmadiyah people. This influenced their involvement in religious mass organizations activities both in sub-district and district levels. The Ahmadiyah's members created their own communities in every villages in Manis Lor. These communities also made them more exclusive in their everyday activities. They only live with their Ahmadiyah's neighbors and they only married with other Ahmadiyah's members.

From the above discussion, it is very clear that Ahmadiyah's community in Manis Lor-Kuningan has several dakwah's strategies as follows: (1) created their own community in villages to consolidate and coordinate among the members; (2) filled local government positions such as head of villages. Since 1970, the village of Manis Lor has been led by Ahmadiyah's members. By occupying head of village positions, it is easy for them to make any local governmental policies for their benefits; (3) established several organizations that affiliated to Ahmadiyah such as Lajnah Ismaillah Manislor organization, Ansharullah organization, and Ikatan Generasi Muda Ahmadi. These organizations actively held several activities for Ahmadiyah's people advantages. Ansharullah organization for example holds agricultural training for Ahmadiyah's farmers, entrepreneurship workshops for young Ahmadiyah's members and provides Ahmadiyah's teachings and learnings for Ahmadiyah's followers.

The case of Ahmadiyah's movement in manis Lor-Kuningan above seems to be different from Ahmadiyah's movement in both districts Tasikmalaya and Garut. Different from their counterpart in Garut and Tasikmalaya, Ahmadiyah's followers in Kuningan have created their exclusive community and consolidated strongly after the conflict. They also actively involved in political contestations in village level particularly during the head village election. They do their best to win the head village election. These have been done by Ahmadiyah's community in Kuningan to strengthen their existence in the region. The case of Ahmadiyah in Kuningan support the argument of Georg
Simmel and Lewis Coser who said that conflict could lead to strengthen and maintain community's identity in society.

This finding in Kuningan is different from what happened in the two previous districts of Garut and Tasikmalaya post conflict period. In Kuningan, the conflict has led to a clearer segregation between Ahmadiyah and non-Ahmadiyah's groups. In can be seen from the fact that Ahmadiyah's people in Manis Lor made their community more exclusive. They do not hold their five daily prayers with non-Ahmadiyah group and only married among Ahmadiyah's members. This exclusivity finally has been resisted by local government (backed by non-Ahmadiyah groups). The local government official did not allow Ahmadiyah's community to have electronic ID card or e-KTP. As a consequence, the Ahmadiyah's members could not give their voice during the Kuningan district election. Because they do not have an official ID card, when they go to religious office or Kantor Urusan Agama to have a married certificate, the local officials rejected them. They could have married certificate if they declared and wrote an official letter stating that they are not an Ahmadiyah's follower anymore.

The post conflict period, Ahmadiyah's group in Manis Lor did not integrate with the non-Ahmadiyah people as what happened in Garut and Tasikmalaya. This, however does not mean that between Ahmadiyah and non-Ahmadiyah group in Kuningan still in conflict. We as researchers called it as quasi integration or a limited integration. It seems that integration or harmony among Ahmadiyah and non-Ahmadiyah in Manis Lor is weak. They are still suspicious each other, though they are living together and do not disturb each other.

\section{CONCLUSION}

From the above discussion, we conclude that the society has its own 'soul'. The soul of society is filled with the soul of its citizens. The citizen who made a nuance and refinement. If its nuance and color are the same, it is easy to make them harmonious. 
However, the differences are natural. If we face differences differently it will lead to a conflict. But if we consider the difference as a natural, it will lead to a harmony. The analogous above seems to be represented by the case of Ahmadiyah's movement in three districts, Kuningan, Tasikmalaya and Garut above. The different views sometimes lead to a conflict and stay the society away from harmonious living as shown in the case of Ahmadiyah's movement in Kuningan. However, the conflict also sometimes could lead to the integration among society as can be seen from the case of Ahmadiyah's community in Tasikmalaya and Garut as discussed above.

\section{ACKNOWLEDGEMENT}

This article is part of a broader research Penelitian Terapan dan Pengembangan Nasional entitled "Konflik Keagamaan di Indonesia: Studi Tentang Pola Konflik dan Model Penanganan Konflik Keagamaan di Jawa Barat funded By LPPM UIN Sunan Gunung Djati, Bandung 2018.

\section{REFERENCES}

Alam, R.H., 2005. Ahmadiyah dan perumusan kebijakan keagamaan di Indonesia, Makalah dalam diskusi yang diadakan Balai Litbang Agama, Depag RI.

As'ad, M., 2009. Ahmadiyah and the freedom of religion in Indonesia. Journal of Indonesian Islam, 3(2), pp. 390-413.

Bain, K. \& Hicks, N., 1998. Building social capital and reaching out to excluded groups: the challenge of partnerships, paper for the CELAM meeting the Struggle against poverty toward and turn of the millennium, 21 April 1998, Washington DC: The World Bank.

Burhani, A.N., 2014. Hating the Ahmadiyya: The place of 'Heretics' in contemporary Indonesian muslim society. Contemporary Islam 8(2), pp.133152.

Connley, A., 2016. Understanding the oppressed: A study of the Ahmadiyah and their strategies for overcoming adversity in contemporary Indonesia. Journal of Current Southeast Asian Affairs 35(1), pp.29-58.

Coser, L.A., 1956. The Functions of Social Conflict. Free Press, New York.

Coser, L.A., 1957. Social conflict and the theory of social change, The British Journal of Sociology, 8(3), pp.197-207.
Creswell, J. W., 1998. Qualitative inquiry and research design: Choosing among five traditions. Sage, Thousand Oaks, CA.

Dahrendorf, R., 1986. Konflik dan integrasi dalam masyarakat industry: Sebuah analisa konflik. Rajawali, Jakarta.

Fadhillah, N.F., 2017. Towards peaceful Islam: Jemaat Ahmadiyah Indonesia as a new social movement. MASYARAKAT: Jurnal Sosiologi, 22(1), pp.35-52.

Fauzi, I.A. \& Hefner, R.W., 2014. Mengelola keberagaman dan kebebasan beragama di Indonesia: Sejarah, teori, dan advokasi. CRCS UGM, Yogyakarta.

Gillespie, P., 2007. Current issues in Indonesian Islam: Analysing the 2005 Council of Indonesian Ulama fatwā no. 7 opposing pluralism, liberalism and secularism. Journal of Islamic Studies, 18(2), pp.202-240.

Goodman, D.J., \& Ritzer, G., 2004. Modern sociological theory, (Alimandan). Prenada Media, Jakarta.

Gross, M., 2003. Sociologists of the unexpected: Edward A. Ross and Georg Simmel on the unintended consequences of modernity. The American Sociologist, Winter, pp.40-57.

Morrow, S. L. \& Smith, M. L., 200o. Qualitative research for counselling psychology. In S. D. Brown and R.W. Lent (Eds.), Handbook of counseling psychology. Wiley, New York.

Naipospos, B.T. \& Halili., 2013. Supremasi intoleransi: Kondisi kebebasan beragama/berkeyakinan dan minoritas keagamaan di Indonesia 2016. Pustaka Masyarakat Setara, Jakarta.

Purwanto, W.H., 2008. Menusuk Ahmadiyah, CMB Press, Jakarta.

Rosidin, D.N., 2010. Islam, Ahmadiyah and the government: Unresolved religious conflicts in Manis Lor Kuningan, West Java. Teologia: Jurnal Ilmu-ilmu Ushuluddin, 21(1), pp.207-226.

Saifuddin, A.F., 1986. Konflik dan integrasi: Perbedaan faham dalam agama Islam. Rajawali Press, Jakarta.

Setara Institute., 2016. Laporan tengah tahun kondisi kebebasan beragama/ berkeyakinan di Indonesia Januari-Juni 2016. SETARA Institute, Jakarta.

Sidik, M., 2008. Dasar-Dasar Hukum dan Legalitas Jemaat Ahmadiyah. Jemaat Ahmadiyah Indonesia, Jakarta.

Sofianto, K., 2011. Gerakan jamaat Ahmadiyah Indonesia Jawa Barat 1931-20oo: Penyebaran ideologi dan respon masyarakat. Fakultas Sain dan Kemanusiaan, UKM, Malaysia.

Syahra, R., 2003. Modal sosial: Konsep dan aplikasi. Jurnal Masyarakat dan Budaya, 5(1).

The Wahid Institute., 2015. Laporan akhir tahun kebebasan beragama/berkeyakinan 2015. The Wahid Institute, Jakarta.

Zulkarnain, I., 2005. Gerakan Ahmadiyah di Indonesia. LKiS, Yogyakarta. 